\title{
The Form of Alawiyyin Relations in Social Life Based on Noble Values and Hereditary Line
}

\section{Wujud Relasi Kaum Alawiyyin dalam Kehidupan Sosial Berbasis pada Keluhuran Nilai dan Garis Keturunan}

\author{
Ikhtiar Hatta \\ Universitas Tadulako, Indonesia. E-mail: ikhtiar_hatta@untad.ac.id
}

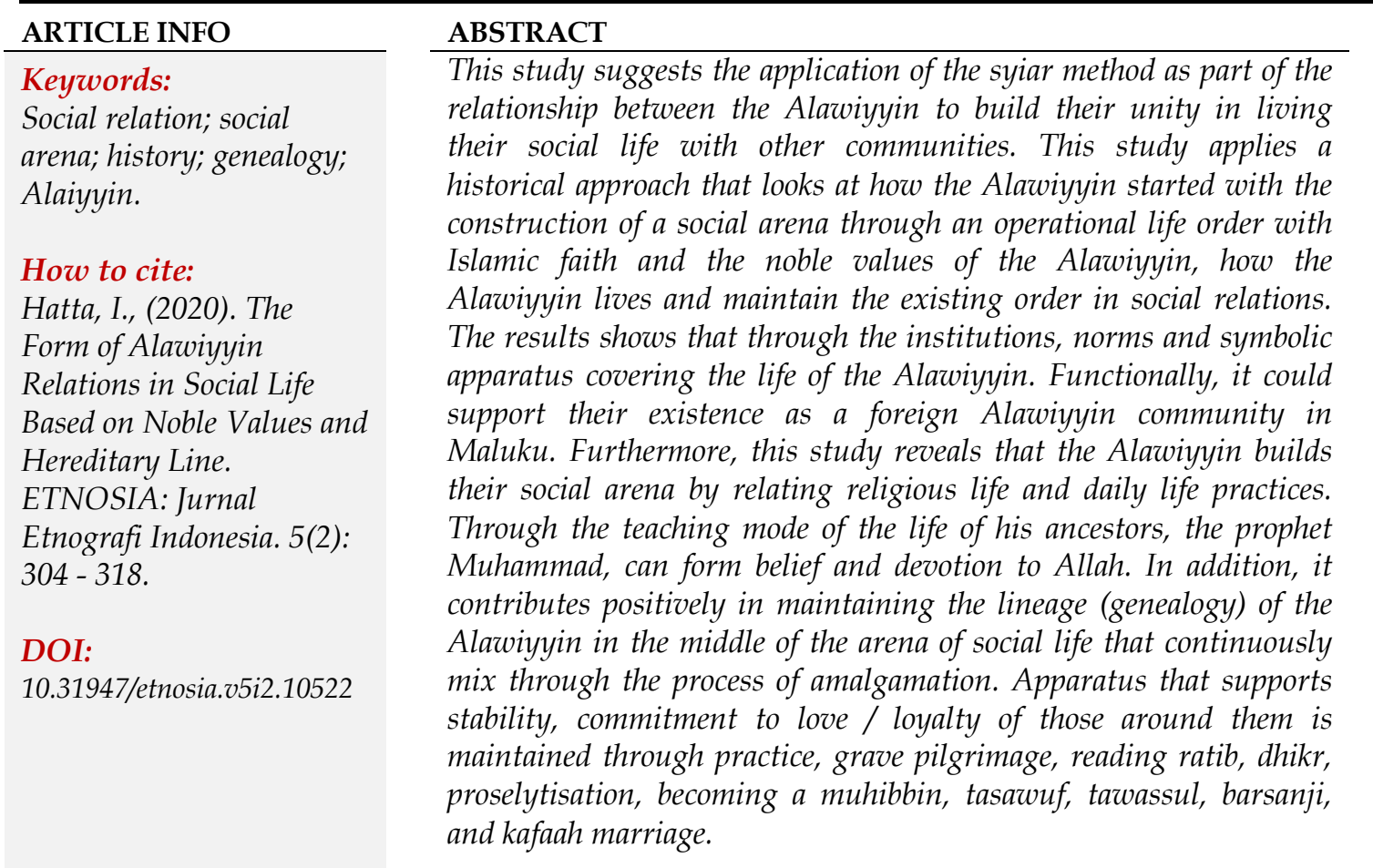

\section{Pendahuluan}

Kajian ini mendiskusikan wujud relasi sosial kaum Alawiyyin sebagai komunitas yang membentuk fenomena diaspora melalui hubungan sosialnya dengan berbagai komunitas di Maluku. Asumsinya bahwa praktek relasi kaum Alawiyyin adalah hasil dialektika nilai-nilai dari dalam komunitas yang telah mengalami pembatinan yang ditarik dari tatanan nilai di negeri Hadramauwt dengan konteks relasi sosial yang berkarakter lokal yang dijalani selama berada di kepulauan Maluku. Artinya, 
kecenderungan analisis dari kajian ini mengikuti kerangka kerja dari pemikir yang menghubungkan studi fenomena yang sifatnya lokal dari sudut pandang komunitas diaspora dengan gejala globalisasi (Slama, 2014), melalui pemahaman fakta empirik dari praktek relasi kaum Alawiyyin dengan komunitas lain secara microscopic. Fokus analisis, dengan demikian lebih menekankan pada sudut pandang kaum Alawiyyin sebagai komunitas diaspora dalam gejala relasi sosial dalam dirinya, relasi dengan kelompok di luar dirinya (penduduk lokal dan komunitas diaspora lainnya) dan masyarakat yang lebih luas.

Kaum alawiyyin yang dikenal jamak sebagai turunan Rasulullah Muhammad SAW (Ho, 2006) (Aidid, 1999), telah menorehkan sejarah yang panjang sebagai satu suku bangsa bermigrasi yang hadir di berbagai belahan dunia (Magenda, 2005). "Mereka [khususnya para pendahulu Ba Alawi/Alawiyyin] menjadi pewaris sekaligus sebagai utusan yang setia, dari Ali dan dua cucu Rasulullah (Hasan \& Husain), mereka telah mewarisi banyak ulama (Alatas, 2012). (Sila, 2004)

Persebaran kaum Alawiyyin/Ba Alawi ke berbagai tempat telah mewarnai signifikansi kehadiran Islam sebagai agama di berbagai tempat dan sebaliknya memosisikan eksistensi kaum Alawiyyin dalam relasi sosial yang lebih luas, di antaranya di Kepulauan Maluku yang menjadi wilayah dalam kajian kali ini. Keberadaan kaum Alawiyyin dan agama Islam adalah dua hal yang sejatinya tidak dipisahkan dalam pembahasan, karena keduanya seperti dua mata uang yang sulit untuk dipisahkan. Lebih jauh, bahkan untuk mendapatkan gambaran yang lebih komprehensif dan mendalam tentang kaum Alawiyyin di Kepulauan Maluku dewasa ini dan agama Islam dibutuhkan keterpaduan dengan melihat peristiwa, tingkah laku dan adab-adab yang dipraktekkan oleh Rasulullah Muhammad SAW dan leluhur kaum Alawiyyin.

Fenomena migrasi seperti di atas jamak dipahami akan membentuk akulturasi ataupun asimilasi. Kelompok pendatang akan tetap berbagi kebudayaan yang sama dengan kebudayaan nenek moyangnya yang dijadikan sebagai pijakan, atau kelompok pendatang dengan kewenangannya mendefenisikan dirinya sendiri (Koenjtaraningrat, 1993) (Patji., 1988) (Kiymlicka, 2011). Pemahaman seperti itu justeru menyisahkan problematisasi karena melihat keberadaan pendatang dari satu sudut pandang dalam memahami dirinya yakni berdasarkan pada nilai-nilai dari leluhurnya atau berdasarkan pada kondisi saat ini yang sedang dijalaninya. Sementara dalam fenomena leluhur kaum Alawiyyin memahami dirinya dan kehidupannya dalam kerangka totalitas. Artinya kehidupan yang dijalaninya mengalami dialektika antara apa yang terjadi saat ini dengan kesadaran sebagai satu kelompok yang terbentuk di negeri Hadramauwt. Bagi kelompok ini, kesadaran sebagai kaum Alawiyyin yang terhubung dengan nazab Rasullullah adalah penting dalam menjalani relasi sosialnya di kepulauan Maluku.

Untuk itu, dalam memahami fenomena tersebut kajian ini memosisikan diri melihat relasi sosial dalam kehidupan kaum Alawiyyin sebagai totalitas dengan menerapkan pendekatan historitas---di mana dalam pendekatan tersebut realitas kehidupan dipahami bersifat totalitas (Rudyansjah, 2009)---kajian ini melihat 
metode dan konfigurasi penerapan nilai luhur dalam kehidupan relasi kaum Alawiyyin yang juga memiliki garis genealogi dengan Rasulullah Muhammad SAW. Lebih lanjut kajian ini juga melihat dialektika dalam konteks pertemuan antara budaya Alawiyyin dengan budaya masyarakat yang didatangi, sehingga kajian tidak menutup mata dalam mengungkap bahwa nilai luhur yang menjadi cetak biru dalam kelompok tersebut tetap mengalami problematisasi, perubahan, terlebih sejak turunan Rasulullah SAW tersebut tersebar ke berbagai belahan dunia, termasuk di kepulauan Maluku, dengan karakter budaya sangat berbeda.

\section{Metode}

Jenis penelitian ini adalah penelitian etnografi dengan mengambil situs penelitian di tiga pulau, yakni Pulau Geser, Pulau Ternate, dan Pulau Ambon. Namun ketiga wilayah tersebut tidak dipahami sepenuhnya sebagai wilayah geografis semata, tetapi wilayah tersebut diletakkan sebagai konteks dari arena relasi sosial. Sebagai penelitian etnografi proses pengumpulan data dilakukan dengan menerapkan metode wawancara mendalam dan observasi berperan-serta. Selama penelitian untuk memperoleh kedalaman informasi/data peneliti menempatkan diri sebagai instrumen utama atau instrumen kunci. Dengan menempatkan diri sebagai instrumen utama dalam mendapatkan data/informasi memungkinkan saya sebagai peneliti hadir secara intensif di tengah mereka dan memahami proses pembentukan pemaknaan informan terhadap saya dan orang lain dalam jalinan relasi sosial yang terwujud di tengah kehidupan mereka. Artinya dengan ikut terlibat dalam interaksi mereka secara intensif dapat memudahkan saya memahami proses dan mekanisme masyarakat membangun relasinya dan menempatkan orang lain dalam struktur relasinya. Data yang diperoleh dari penelitian ini dianalisis dalam tiga tahapan yakni, reduksi data, penyajian data dan generalisasi atau kesimpulan atas beragam konteks dari fenomena yang ditemukan di tiga lokasi penelitian.

Tabel 1. Daftar Informan

\begin{tabular}{clcc}
\hline \multicolumn{2}{c}{ Nama informan } & Suku bangsa \\
\hline No. & \multicolumn{2}{c}{ Lokasi Geser/Bula } & \\
\hline 1. & Abdulkadir bin Idris Alhamid & Alawiyyin (Arab) \\
\hline 2. & H. Fattah Khouw & (Turunan Cina) \\
\hline 3. & H. Islam Alkariri & Masayekh (Arab) \\
\hline 4. & Mama Econg Alhamid & Sarifah Alawiyyin (Arab) \\
\hline 5. & Abdurrahman bin Abdulkadir & Ahwal (Bugis) \\
\hline & & Lokasi Ambon & \\
\hline 1. & Dr. Husen Assagaf. & Alawiyyin (Arab) \\
\hline 2. & Hasan Bin Syehk Abubakar & Alawiyyin (Arab) \\
\hline 3. & Dedy/Jafar Djamalullail & Alawiyyin (Arab) \\
\hline 4. & Pendeta John Chr. Ruhulessin & Ambon (Tokoh Masy.) \\
\hline 5. & Rifki Alhamid & Alawiyyin (Arab) \\
\hline & & Lokasi Ternate & \\
\hline 1. & Syarifah Ummi & Sarifah Alawiyyin (Arab) \\
\hline 2. & Abubakar Alatas & Alawiyyin (Arab) \\
\hline 3. & Fadly Albaar & Alawiyyin (Arab) \\
\hline 4. & Oji Alhadar & Alawiyyin (Arab) \\
\hline 5. & Fahmi Alhadar & Alawiyyin (Arab) \\
\hline
\end{tabular}




\section{Hasil Penelitian dan Pembahasan}

\section{Membangun Pondasi Arena Relasi}

\section{- Berawal dari Historisitas Rasulullah Muhammad SAW.}

Berawal dari historisitas cerita kenabian Rasulullah Muhammad SAW dimana sebagian besar sumbernya dirujuk dari kisah-kisah yang sudah dituliskan oleh berbagai sejarawan atau pemikir yang menggeluti topik sejarah kehidupan Rasulullah. Karena itu apa yang dipaparkan dalam bagian ini boleh jadi sudah ditemukan substansinya pada kajian yang lain, namun untuk memberikan latar historis ${ }^{1}$ yang kuat dari tulisan ini sebagai dasar nilai bagi kaum Alawiyyin di Maluku, maka cerita singkat perjuangan dan dakwah Rasulullah tetap menjadi signifikan diuraikan dalam kajian ini.

Kajian ini menempatkan historisitas Rasulullah Muhammad SAW, dalam konteks syiar Islam/dakwah, dan dinul Islam. Sebagai sebuah realitas keduanya tidak dapat dipisahkan satu dengan yang lainnya untuk membangun pemahaman yang komprehensif mengenai keberadaan dan logika relasi kaum Alawiyyin. Di sisi lain, keduanya berpadu membentuk satu matarantai keyakinan yang teguh mengenai hakikat keberagamaan orang Islam di kepulauan Maluku.

Dalam peta keyakinan Islam, Rasulullah Muhammad SAW (Hatta \& Dkk., 2013) dikenal luas sebagai Nabi dan Rasul ${ }^{2}$ bagi umat Islam dan tentunya sekaligus yang pertama kali mendakwahkan agama Islam. Dalam sejarahnya beliau diutus menjadi rasul ke tengah umat manusia pada masanya untuk memperbaiki akhlak manusia dengan melalui proses pewahyuan (Hatta \& Dkk., 2013). Dalam sejarah penyebaran agama Islam yang dilakukan oleh Rasulullah Muhammad SAW cetak birunya adalah dakwah dan pemosisian Islam sebagai agama rahmatan lilalamin. Kegiatan dakwah Rasulullah tersebut secara sosial tentu syarat dengan duri berupa resistensi dari orang atau kelompok yang merasa tidak Hadramauwt karena terancam eksistensinya. Jamak diketahui bahwa awalnya beliau menyebarkan Islam kepada orang-orang terdekatnya melalui pendekatan individual, terutama dalam keluarga besar serta para sahabat karibnya. Mereka inilah dalam Islam dikenal dengan istilah as-Sabiqun alAwwalun/orang-orang yang paling dahulu masuk Islam. Dari sini dapat dilihat bagaimana Rasulullah dalam syiar Islam penuh kehati-hatian.

Masa awal syiar Rasulullah SAW belum menyinggung tentang tuhan dan agama kaum Quraisy sembah, sebuah mekanisme syiar yang secara sosial cukup elegan menghindari reaksi yang berlebihan dari kaum Kuraisi pada zamannya, mengingat persinggungan tentang wilayah ketuhanan pada suatu masyarakat yang memiliki keteguhan keyakinan akan tuhannya sangatlah beresiko.

1 Dalam kesempatan wawancara dengan informan Alawiyyin, ia senantiasa merujuk ke apa yang dipraktekkan dan disampaikan oleh Rasulullah SAW sebagai Nabi dan sebagai leluhurnya. Sebagai keturunan Nabi Muhammad SAW apa yang dilakukan oleh Rasulullah pada masa kenabiannya dalam berdakwah sejatinya juga diikuti oleh anak cucunya/turunannya dalam prakteknya di kehidupan sosial.

2 Rasul adalah orang yang diutus Allah dengan syariat yang baru untuk menyeru manusia kepadaNya. Sedangkan Nabi adalah orang yang diutus Allah untuk menetapkan (menjalankan) Syariat rasul sebelumnya. 
Penetrasi seperti ini tentunya cukup efektif meredam kemarahan utamanya mereka yang diketahui tidak suka, dan secara perlahan dakwah secara sembunyi mulai menampakkan hasil. Komunitas orang-orang beriman perlahan terbentuk. Rasulullah SAW mempersatukan mereka dalam ikatan persaudaraan (ukhuwah), saling, menolong, saling menanggung beban dan menyampaikan risalah secara pasti.

Dakwah terbuka mulai dipraktekkan oleh Rasulullah terutama sekali menghadapi kebatilan Dakwah secara terbuka dilakukan ketika Allah menurunkan perintahnya: "Maka sampaikanlah (Muhammad) secara terang-terangan segala apa yang diperintahkan (kepadamu)" (QS. Al-Hijr [15]: 94). Dalam kisahnya Rasulullah SAW mengundang anggota keluarga terdekatnya Bani Hasyim, namun dalam kesempatan itu hadir juga dari kabila lainnya, yakni Bani al-Muthallib 'bin Manaf. Abu Lahab yang dikenal sebagai tokoh yang sangat keras menentang kegiatan dakwah Rasulullah turut hadir dan memberikan reaksi yang kurang simpatik bahkan mengejek dan berusaha mempengaruhi yang hadir agar tidak mengakui apa yang dikatakan Muhammad SAW, alih-alih masyarakat menjauh sebaliknya yang terjadi pengikutnya semakin bertambah. Poin penting yang dapat kita lihat disini adalah Tabligh yang disampaikan oleh Rasulullah SAW secara terbuka memberikan makna bahwa beliau pertama, sangat amanah dalam menyampaikan wahyu kepada umatnya; kedua, nabi memperlihatkan kejujurannya dalam menyampaikan ajaran Allah SWT kepada umatnya, dan mustahil kitman (menyembunyikan wahyu) (Hatta \& Dkk., 2013). Sifat ini sebenarnya merujuk pada Nabi dan Rasul sebelumnya yang selalu menyampaikan wahyu apapun bahaya yang datang kepada mereka (Arab, 1994).

Semua kejadian dan kehidupan yang dialami oleh Rasulullah yang sudah tergambar dalam berbagai kisah dan kitab-kitab yang ditulis oleh para ulama---termasuk kejadian yang dialami oleh Sayyidina Ali dan kedua anaknya yakni Imam Hasan dan Imam Husain---senantiasa menjadi rujukan dan direlasikan dengan kehidupan orang Alawiyyin di Kepulauan Maluku. Misalnya saja ia melarang anak-anaknya main bola demi menghargai dan menjaga kebesaran dan kesucian Imam Husain, karena pada saat peristiwa Karbala kepala Imam Husain terpotong dan ditendang-tendang oleh para musuhnya. Peristiwa di masa kenabian dan masa kehidupan Ahlulbait ini menjadi awal referensi tabuh (Alatas, 2012) bagi mereka untuk tidak melakukan perbuatan yang menyerupai perlakuan yang menyakitkan hati turunan Rasulullah (Reysyahri, 2015). Sebuah kejadian kecelakaan dan menyebabkan salah satu giginya tercabut menjadi satu peristiwa yang wajar tetapi sekaligus penuh dengan hikmah pembuktian kedekatan kepada Rasulullah Muhammad SAW, bahwasanya apa yang terjadi tersebut sebagai bukti kalau ia betul-betul adalah turunan Rasulullah karena itu harus diterima dengan ikhlas dan bersyukur.

\section{- Konteks Sosial-Budaya Masyarakat di Kepulauan Maluku pada Awal} Keberadaan Islam dan Kaum Alawiyyin.

Maluku sebagai sebuah wilayah yang berpenghuni sudah diakui eksistensinya jauh sebelum kedatangan bangsa-bangsa kolonialis menanamkan kekuatan dan pengaruhnya. Masyarakat di kepulauan Maluku, khususnya di Ambon sejak dulu 
dikenal luas sebagai masyarakat heterogen. Di atas wilayah ini pada mulanya terdapat sejumlah kerajaan-kerajaan, Ibnu Bathutah kemudian menempatkan kepulauan Maluku ke dalam kawasan negeri para raja-raja/semenanjung Raja-raja (Al-jazirah almuluk). Menurut catatan sejarawan, Maluku terdiri dari berbagai macam suku---hal yang sama juga sering dijumpai di wilayah lain---yang berdiam dalam wilayah tertentu di pegunungan, misalnya di Manusela, pegunungan Batik yang ada di Pulau Seram Besar. Pulau seram bagi orang Ambon adalah pulau Induk, karena itu disebut juga dengan "Nusa Ina" atau pulau Ibu, atau pulau dari mana mereka berasal. Di tengah pulau Induk tersebut terdapat sub suku atau fam-fam seperti fam Wattimena, Lokollo, Kakisina, Korputty, Kakerissa, Riupassa, Anakotta, Payapo, Pesireron, Manuputty, Pasal, Pasanea, Kiry, Killia, Tamaela, Soutssa, Lessy dan lain-lain (Trijono, 2001). Selain itu, bagi orang Maluku juga mengenal tingkatan ikatan keluarga, mulai dari klan-klan atau kelompok berdasarkan keturunan yang mendiami rumahtaurumahtau. Rumahtau ini kemudian membentuk teritori pemukiman yang disebut dengan Uku, selanjutnya membentuk Uli. Di ambon dikenal dua Uli yakni Ulisiwa dan Ulilima, di bagian lain dikenal dengan Patasiwa dan Patalima. Begitu halnya dengan orang Nuaulu salah satu suku yang berasal dari pedalaman Pulau Seram menyebutkan bahwa leluhur mereka adalah orang-orang yang berasal dari tempat yang bernama Nunusaku, sebuah wilayah yang diduga berada di Kecamatan Wahai, di Pulau Seram bagian utara pada suatu tempat yang bernama Hatu Supu (batu kuat/patokan) letaknya pada wilayah di atas Negeri Sawai dan Negeri Saleman. Nama Teon negeri dari masyarakat Nuaulu adalah Risapoli Leisela diartikan "perang, nanti menang", karena Leisela artinya lebih. Dalam hal ini leluhur orang Nuaulu menganggap mereka sebagai orang-orang yang memiliki keahlian berperang lebih dari yang lain (Nina, 2012). Kehidupan leluhur masyarakat Maluku pada saat itu sebagian besar masih berpindah-pindah (nomaden) mencari tempat tinggal yang baik.

Mengenai sistem kepercayaannya diyakini masih menganut sistem kepercayaan animisme, ada juga mengenalnya dengan alifuru. Agama-agama monoteisme seperti agama Islam dan agama Kristen menyusul kemudian, begitu juga dengan Konghucu. Agama Islam sendiri masuk ke wilayah Maluku terjadi pada pertengahan abad ke-15 (Benda, 1980: 27). Sejak masuknya Islam ke wilayah tersebut kehidupan sosial mengalami penataan baru dalam hal tatanan sosial. Satu hal yang sangat problematis dewasa ini adalah perdebatan tentang siapa dan dari golongan mana yang pertama kali menyebarkan Islam di wilayah Maluku, namun dalam berbagai catatan menunjukkan bahwa kehadiran Islam selalu dikaitkan dengan kelompok masyarakat yang terlibat dan menonjol dalam perdagangan. Konsekuensi dari pemahaman tersebut menempatkan pemikiran bahwa penyebar agama Islam yang pertama dilakukan oleh bangsa-bangsa seperti India, Pakistan, Turki dan Cina yang sudah memeluk Islam, artinya dapat dikatakan bahwa agama Islam pertama kali hadir di Indonesia melalui tangan kedua.

Pemikiran seperti itu mendapat sanggahan dari sejumlah anggota komunitas Alawiyyin di kepulauan Maluku. Menurut keterangan dan bukti-bukti yang dimiliki oleh mereka, bahwa kehadiran Agama Islam pertama kali di kepulauan Maluku tidak 
lepas dari buah tangan leluhur kaum Alawiyyin yang melakukan syiar Islam dengan berdakwah ke berbagai tempat di Nusantara. Dalam cerita yang diperoleh dari leluhurnya (walaiti) menjelaskan bahwa pada saat menginjakkan kaki pertama kali di kepulauan Maluku leluhurnya masih menemukan kehidupan orang di kepulauan Maluku pada umumnya masih menganut kepercayaan animisme---seperti penjelasan sebelumnya---dan memiliki kebiasaan berperang antara satu kelompok dengan kelompok yang lainnya. Tradisi memotong kepala yang dijadikan sebagai tumbal dalam kelompoknya membuat masyarakat harus selalu dalam keadaan siap-siaga atas kelompok yang lain, dan seringkali kekalahan satu kelompok atas kelompok yang lain memaksa mereka berpindah dan mencari tempat yang lebih aman. Dalam cerita yang diyakini oleh mereka leluhur kaum Alawiyyin seringkali harus memperlihatkan kemampuannya atau karomahnya (pembahasan lebih lanjut tentang kekuatankekuatan supernatural dan karomahnya dapat ditemukan pada penjelasan setelah poin ini) ketika berhadapan pertama kali dengan mereka.

\section{Orientasi Diaspora Kaum Alawiyyin di Maluku}

\section{- Fase Awal: Kontekstualisasi Mode Awal Relasi Kaum Walaiti di Kepulauan Maluku}

Generasi pertama kaum Alawiyyin adalah generasi yang datang langsung dari Hadramauwt (Assegaf, 1994). Mereka ini dikenal di kepulauan Maluku dengan sebutan Walaiti. Tidak banyak yang mengetahui siapa saja yang pertama kali dan dari marga apa, namun yang pasti, mereka yang datang tersebut adalah turunan Rasulullah yang lahir di tanah Hadramaut (biasa juga dikenal dengan "Alawiyyin Totok"). Umumnya mereka datang tidak dengan isterinya atau Syarifah. Mereka datang masih usia muda, karena itu mereka cukup luwes membangun relasi dalam berbagai dimensi dengan masyarakat. Namun berbeda hal pemahaman yang disampaikan oleh Hurgronje yang mengatakan bahwa Islam masuk ke Nusantara melalui tangan kedua (Hurgronje, n.d.) (Hurgronje, 2019).

Berikut ini adalah beberapa kontekstualisasi model relasi kaum alawiyyin di kepulauan Maluku dalam kerangka syiar/dakwah agama Islam. Pertama, Model yang terbentuk dalam menciptakan relasi yang baik dengan penduduk setempat adalah dengan menempatkan Mu'jizat, Keutamaan Atau Karomah. Model ini diperoleh informasi bahwa, kehadiran generasi pertama ini ada yang datang karena mendapatkan petunjuk dan arahan dari para gurunya di Hadramaut (orang tua dalam hal ini ayah, kakek, atau paman tidak jarang menjadi guru bagi anak-anak mereka) untuk datang dan melakukan syiar Islam di kepulauan Maluku. Walaupun tidak diketahui darimana mereka mengenal kepulauan tersebut, namun hampir semua turunannya yang sempat diwawancarai menjelaskan bahwa guru-guru mereka adalah orang-orang suci, Wali Allah yang memiliki karomah atau mu'jizat. Kelebihan ilmu leluhurnya yang berada di Hadramauwt adalah kekuatan tersendiri dalam mengarahkan murid-murid mereka melakukan perjalanan ke negeri-negeri yang ditunjuk, di antarnya di kepulauan Maluku, sebuah negeri yang jauh. 
Selain guru mereka memiliki mu'jizat atau karomah, tidak jarang murid-murid yang datang ke kepulauan Maluku juga memiliki kemampuan, mu'jizat atau karomah. Namun demikian, perlu ditegaskan bahwa kelebihan-kelebihan yang mereka miliki tidak serta-merta dan setiap waktu dapat digunakan sesuka hatinya. Kelebihankelebihan yang dimiliki menurut informasi lebih banyak digunakan sebagai pembuka jalan dalam membangun hubungan untuk masuk ke suatu komunitas di Maluku. Seperti yang telah dijelaskan sebelumnya bahwa, kedatangan generasi walaiti ke kepulauan Maluku, kehidupan sosial masyarakat masih diliputi oleh situasi perang antar kelompok. Dapat dibayangkan kehadiran orang luar yang baru datang dan tidak dikenal di wilayah dengan kondisi kehidupan yang selalu dalam suasana perang, tentunya akan mendapatkan perhatian khusus di antaranya akan dicurigai, lebih jauh akan diuji nyalinya dengan perang atau perkelahian.

Kondisi inilah menjadi jalan generasi walaity (Generasi Walaity adalah mereka yang terlahir dari ayah dan ibu yang belum mengalami percampuran dengan penduduk lokal. Generasi ini umumnya lahir dan datang dari Hadramauwt) terpaksa memperlihatkan kemampuan atau kelebihannya, tidak harus berperang atau berduel tetapi cukup dengan mengekspresikan kelebihan seperti beradu mengangkat batu dengan diameter dan beban yang berat, atau hanya dengan menunjuk burung yang terbang, burung itu langsung terjatuh ke tanah. Ekspresi kekuatan lainnya dalam melakukan pendekatan dan membangun integrasi ke komunitas-komunitas di Maluku adalah dengan memberikan pengobatan kepada warga yang menderita sakit. Dengan kekuatan dan cara tertentu melakukan pengobatan, si pasien menjadi sembuh, atau ketika tiba di suatu tempat yang tidak terdapat sumber air, dengan mu'jizat yang dimiliki menancapkan tongkat di suatu tempat dan keluarlah air yang akhirnya digunakan sebagai sumber air dalam rangka memenuhi kebutuhan satu kampung. ${ }^{3}$

Lebih lanjut, perlu dijelaskan bahwa apa yang dilakukan dengan memperlihatkan berbagai kemampuan atau karomah, mu'jizat tentunya memiliki alasan yang sifatnya kontekstual, dan yang paling penting adalah bertujuan melakukan penetrasi terhadap anggota masyarakat yang didatanginya. Ekspresi kekuatan dan mu'jizat secara analitis menjadi jalan membangun penghormatan, ketundukan, dan loyalitas baik oleh pimpinan dari suatu komunitas dan juga seluruh anggotanya. Dengan pendekatan seperti itu generasi walaiti terterima dan terintegtasi dengan suatu kelompok. Pintu masuk seperti itulah menjadi jalur menyampaikan agama Islam ke tengah-tengah masyarakat.

Kedua, Model dalam membentuk relasi sosial yang lebih aman yakni melalui pernikahan. Keberadaan turunan kaum Alawiyyin di kepulauan Maluku dewasa ini menjadi bukti otentik terjadinya perkawinan antara golongan walaiti dengan perempuan lokal di kepulauan Maluku. Perkawinan yang dilakukan pada posisi ini

\footnotetext{
${ }^{3}$ Cerita yang tidak terjangkau oleh nalar seperti di atas masih mewarnai alam pemikiran sebagian orang yang saya temui di kepulauan Maluku tepatnya di Geser dan Bula, serta di Ternate (ketiga wilayah tersebut adalah lokasi penelitian disertasi saya). Bahkan di era yang mengedepankan rasionalitas dewasa ini sekalipun terjadi sebuah kejadian, seorang Habib di Geser memperlihatkan kemampuannya melepaskan hidungnya.
} 
tidak bermaksud melihat dalam perspektif gender. Hemat kami, menempatkan pernikahanyang dilakukan oleh kaum alawiyyin dalam perspektif gender dapat dipastikan berakhir dengan kesimpulan menempatkan model pernikahan tersebut bias gender, mengingat kaum Alawiyyin tidak memperkenankan syarifahnya menikah dengan orang di luar dari kelompok Alawiyyin, hal berbeda bagi laki-lakinya memungkin menikah dengan perempuan di luar dari kelompoknya. Dari sudut pandang gender posisi laki-laki dan perempuan dipastikan ditemukan ketimpangan dan ketidakadilan atasnya. Memahami realitas alawiyyin dalam konteks perkawinan seperti ini justeru akan menutup adanya potensi lain dalam mendiskusikan fenomena relasi yang dibangun oleh kelompok tersebut.

Selain itu, sejumlah peneliti memiliki kesimpulan bahwa, Islam merupakan faktor penting dalam mudahnya perkawinan mereka para imigran dari Hadramauwt--Negeri Hadramauwt---dengan penduduk lokal. Mereka menganggap agama yang sama dengan masyarakat pribumi telah membuat integrasi lebih mudah terjadi dibandingkan dalam kasus Cina-Hindia (Kesheh, 2007). Pernyataan ini menjadi betul ketika Islam sudah banyak tersebar dan dianut oleh masyarakat lokal di Nusantara termasuk di kepulauan Maluku. Namun demikian penelitian ini menemukan hal berbeda, perkawinan kaum alawiyyin sejatinya dipahami sebagai bagian integral dari dimensi penguatan dan penjagaan kesucian dan aqidah Islam yang dibawa oleh Rasulullah (Muhammad Hasan Al-Aydrus, 1996). Memisahkannya tentunya akan membawa pada penjelasan yang tidak komprehensif dan mendalam tentang islam dan kaum Alawiyyin.

Dalam konteks kaum Alawiyyin di kepulauan Maluku, pernikahan yang dilakukannya sangat tergantung dari pada periode kedatangan. Kaum Alawiyyin yang datang pada gelombang sebelum Islam menjadi agama yang tersebar luas di kepulauan Maluku akan berbeda dengan pada saat setelah Islam menjadi agama yang diterima secara luas. Menurut Informasi yang diperoleh dari informan menjelaskan bahwa mereka yang datang pertama kali berstatus sebagai walaiti (pure) tidak datang bersama perempuan/syarifahnya. Umumnya mereka datang sendiri dengan usia yang relatif mudah. Ketika berada di suatu tempat untuk syiar Islam mereka juga menikahi perempuan lokal di mana mereka singgah, namun sebelum menikahinya ia terlebih dahulu mengislamkan perempuan yang menjadi calon isterinya.

Gelombang pertama inilah yang mengawali melakukan perkawinan campuran dengan perempuan lokal. Namun setelah populasi kaum Alawiyyin di kepulauan Maluku semakin bertambah jumlahnya, akhirnya terbentuk satu kesepakatan yang tidak tertulis di dalam kelompok Alawiyyin agar laki-laki generasi berikutnya menikah dengan perempuan dari golongan syarifah. Walaupun tidak semua mengarahkan anak laki-lakinya menikah dengan perempuan dari golongan syarifah, tetapi menjadi suatu kegembiraan jika hal itu terjadi, dan memiliki gengsi sosial di kalangan mereka. Bahkan ada kasus beberapa keluarga menempatkan perkawinan laki-laki Alawiyyin 
dengan wanita di luar Alawiyyin hampir disamakan hukum tabuhnya dengan pernikahan seorang syarifah dengan laki-laki di luar kelompok Alawiyyin.4

Kaum Alawiyyin---baik Habib ataupun Syarifah---yang melakukan pernikahan dengan anggota dari komunitas lainnya pada dasarnya tetap dianggap sah atau legal dari sisi Islam sejauh memenuhi ketentuan syariat dalam perkawinan yang telah digariskan dalam agama Islam. Tetapi demi menjaga keberlangsung kemurnian dan kesucian turunan Ahlul Bait sebagai satu bagian dari cara dalam menjaga kesucian dan kemurnian Islam dalam dimensi nasab genealogis sekaligus beriringan dengan nasab ilmu, maka pernikahan keluar baik oleh habib terlebih pada syarifah menjadi "terlarang".

Pemeliharaan kemurnian ajaran agama Islam dapat dilakukan melalui jalur nasab biologis dan nasab ilmu. Nasab ilmu adalah dengan melihat alur turunan ajaran yang disampaikan apakah sampai ke Rasulullah Muhammad SAW atau tidak. Sementara penjagaan kesucian ajaran Islam yang paling paripurna adalah melalui penjagaan nasab biologis. Untuk itu, sebagai pewaris nabi, mereka bisa menghadirkan pengetahuan mereka yang mendalam tentang kata-kata nabi dan perbuatan melalui dhahabiyya silsilah (rantai emas), rantai pengetahuan ditransmisikan secara internal melalui keluarga dari ayah ke anak tanpa mediasi eksternal (Alatas, 2012).

Ketiga, Model dari proses integrasi antara kaum Alawiyyin dengan penduduk lokal adalah melalui hubungan perdagangan Kehadiran orang Arab secara umum dalam berbagai kajian baik yang sifatnya historis ataupun antropologi pada umumnya menempatkan perdagangan sebagai orientasi utama yang mendorong keberadaan mereka di kepulauan Maluku. Tidak bisa dipungkiri orang Arab dalam sejarah Rasulullah pun menjadikan perdagangan sebagai mata pencaharian yang sangat inti dan signifikan dalam melangsungkan kehidupannya (survival). ${ }^{5}$

Begitu juga yang dilakukan oleh Arab Hadrami ${ }^{6}$ di berbagai tempat di Nusantara. Mereka mengunjungi tempat-tempat di berbagai wilayah di Nusantara dengan tujuan melakukan perdagangan. Mereka sangat dipengaruhi oleh dongeng keberuntungan, yang membawanya melakukan migrasi ke Asia Tenggara sekitar akhir pertengahan abad kedelapan belas (Kesheh, 2007). Praktis sebenarnya semua imigran Hadrami bekerja dan berkembang awalnya melalui usaha perdagangan (Kesheh, 2007).

Namun menjadi persoalan adalah apakah perdagangan menjadi orientasi utama kehadiran mereka di kepulauan Maluku. Menurut keterangan yang diperoleh bahwa leluhur mereka pada saat awal kedatangannya---untuk gelombang yang datang

\footnotetext{
4 Syarifa Ummi (bukan nama sebenarnya) pada kesempatan lain menjelaskan bahwa ia menuntut anakanak laki-laki dan perempuannya mengambil pasangan dari golongan alawiyyin. Pernikahan anakanaknya dari golongan alawiyyin menjadi satu kesyukuran tersendiri, dan sekaligus menjalankan amanah dari almarhum suaminya.

5 Diceritakan dalam berbagai kisah bahwa Rasulullah sebelum diangkat menjadi seorang Rasul pun adalah seorang pedagang, namun beliau dikenal sebagai pedagang yang jujur tidak berorientasi keuntungan semata.

${ }^{6}$ Berbicara tentang Arab Hadrami dalam tulisan ini berarti berbicara tentang orang Arab Hadrami secara umum dari berbagai komunitas tanpa kecuali.
} 
mengikuti kapal uap milik pedagang eropa---mereka memang turut serta melakukan aktifitas berdagang, tetapi bukan menjadi orientasi utama. Menjadi seorang pedagang lebih bertujuan menyambung hidup, bukan mencari sebesar-besarnya keuntungan. Mode perdagangan yang dipraktekkan seperti ini merujuk pada apa yang dilakukan oleh Rasulullah Muhammad SAW, perdagangan dijadikan sebagai jalan Dakwah kepada umatnya (Muhaimin \& Wahab, 2014).

\section{- Fase Lanjutan: Penanaman Ilmu}

Fase Awal yang dijelaskan di atas memuat visi yang lebih banyak memperkenalkan dan menyebarkan/syiar Islam ke tengah masyarakat, maka pada Fase lanjutan ini penguatan visinya lebih kearah melakukan penguatan ilmu, baik yang dilakukan oleh generasi kaum Alawiyyin yang datang dari hadramaut atau yang sudah lahir besar di Nusantara dan di wilayah negara lain. Keberadaan mereka tidak lagi banyak mendapatkan tantangan seperti yang dialami oleh generasi sebelumnya. Fase ini menanamkan ilmu untuk menguatkan keimanan dan ketakwaan orang yang sudah masuk ke dalam Islam dengan mengajarkan syariat, aqidah dan Tarikat. Namun pun demikian proses perkawinan, perdagangan juga masih tetap dipraktekkan pada generasi ini.

Salah satu konfigurasi model pada fase ini mereka kenal dengan istilah Ilmu Tikar. Konfigurasi model ini adalah suatu peristilahan yang digunakan oleh orang-orang yang pernah berguru ilmu tasawuf dan syariat kepada sejumlah mursyid.7 Mereka yang menjadi mursyid pada umumnya adalah kaum Alawiyyin. Dalam ilmu tikar muatan yang diberikan memiliki keragaman, namun yang paling umum adalah ilmu Tasawuf atau Tariqat. Di kepulauan Maluku ilmu tersebut sangat diminati dan diburu, karena selain dapat meneguhkan dan mendekatkan diri pada Allah, ilmu ini juga mereka yakini mampu memberikan keutamaan atau mu'jizat bagi yang menggelutinya dengan serius dan baik. Karena itulah, ilmu ini tidak sembarang orang diberikan. Sang guru/mursyid memiliki kemampuan mengetahui murid yang mana yang pantas menerima ilmu pada tingkat pertama, kedua dan seterusnya. Ilmu tikar juga biasanya lebih bersifat rahasia dan terbatas (limited).

Karena itu, setiap orang memiliki peluang mendapatkan ilmu yang berbeda antara murid yang satu dengan murid yang lainnya. Murid yang memiliki keteguhan dalam menuntut ilmu dapat dipastikan mendapatkan ilmu lebih banyak, beragam dan mendalam jika dibandingkan dengan seorang murid yang hanya duduk dan tidak memperlihatkan keteguhan dan keseriusannya mencari ilmu dalam arti betul-betul membutuhkan, dengan cara meminta/bertanya.

Seorang guru/mursyid dalam ilmu tikar tidak serta merta memberikan ilmunya ketika ada seorang murid meminta/bertanya, untuk menguji keseriusan dan komitmen seorang murid, seorang mursyid seringkali memberikan berbagai ujian yang bertingkat. Jika sang murid memperlihatkan keseriusan dan komitmen, pada saat

\footnotetext{
7 Sebutan pada guru yang berilmu tinggi dan mengajarkan ilmu syariat dan tarikat atau tasawuf pada seorang murid atau pencari ilmu di kepulauan Maluku.
} 
itulah sang mursyid menurunkan ilmunya pada seorang yang sudah memiliki status murid.

Seorang murid yang notabene adalah seorang Alawiyyin tidak serta merta/otomatis mendapatkan ilmu dari seorang mursyid walaupun mursyid adalah orang tuanya (baik Abah, Ami, atau datu'nya). Sebagai murid ia juga harus melalui proses yang sama untuk memperlihatkan loyalitas, keseriusan dan memiliki kecintaannya (mahabbah) pada musryidnya, Wali Allah, Rasulullah Muhammad SAW, dan Mahabbah Allah SWT. Berbeda dengan ilmu tikar, ilmu klasikal tidak memiliki kerahasiaan. Ilmu ini umumnya mengajarkan tentang syariat, dan kebanyakan diajarkan di dalam kelas dengan menggunakan bangku. Metode ini menyerap mekanisme pendidikan formal yang dilakukan dalam penuntutan ilmu pengetahuan umum.

\section{Pembentukan dan Keberlajutan Loyalitas dalam Relasi Sosial}

Melalui syiar Islam yang dilakukan oleh generasi walaiti pada awal persebaran Islam dengan mengukuhkan keyakinan berdasarkan Al-Qur'an dan sunnah Rasul, maka terbentuklah arena kehidupan sosial yang kondusif untuk menjalankan relasi sosial bagi kaum Alawiyyin (Muhaimin \& Wahab, 2014). Kondisi ini pada gilirannya bermuara membentuk ketaqwaan kepada Allah SWT. Hanya saja, ketaqwaan tidak bisa stabil kecuali senantiasa dilakukan pemeliharaan, pensucian, penyadaran melalui berbagai aparatus di antaranya: siarah kubur, kegiatan siarah kubur yang dilakukan ke makam waliyullah, atau orang-orang yang memiliki karomah, mu'jizad adalah satu mekanisme memanggil kembali ingatan-ingatan hubungan yang sudah terjalin antara leluhur. Ingatan ini selain meromantisasi juga membangun harmonisasi dan loyalitas pada mereka yang memiliki keterkaitan dengan makam keramat, baik pada internal Alawiyyin ataupun pada komunitas lainnya.

Praktek zikir bersama, dakwah, menjadi seorang muhibbin, tasawuf, tawassul, barsanji, Maulid dan pernikahan se-kafaah dan pembacaan ratib menjadi kanon dalam menjaga tatanan hubungan yang baik di tengah mayarakat. Berbagai ekspresi tersebut diyakini bernilai doa kepada Allah SWT dan kecintaan kepada Rasulullah Muhammad SAW dn para waliyullah. Kegiatan ini selain memberikan spirit ketaqwaan bagi para jamaah, juga membangun emosi kedekatan kepada para Waliullah dan turunan Rasulullah yang memiliki maqam yang tinggi disisi Allah SWT, dan membias kepada keturunan mereka dalam bentuk relasi muhibbin, sebuah relasi yang mencintai dan menghargai keturunan Rasulullah karena kecintaan pada Nabi Muhammad SAW. Pola relasi yang terbentuk antara penduduk lokal dengan kaum Alawiyyin yang diyakini sebagai waliyullah pewaris sifat dan nilai nabi menjadi fakta bahwa wujud relasi ini tidak memisahkan antara kehidupan kongkrit dengan kehidupan rohani.

\section{Wujud Relasi Kaum Alawiyyin di Kepulauan Maluku}

Diaspora yang dijalankan oleh kaum Alawiyyin memiliki visi yang berbeda dengan apa yang dilakukan oleh komunitas lain seperti orang Cina, Bugis dan Buton dan sebagian orang Arab dari komunitas yang berbeda. Bagi orang Cina, Bugis dan Buton 
melakukan persebaran dimotivasi oleh daya keberlangsungan hidup (survive) yang berorientasi ekonomis (economyc oriented), sehingga mereka terdorong menjalani aktivitas sebagai pedagang untuk menguatkan dimensi ekonomi dalam kehidupannya. Perdagangan pada akhirnya menjadi arena sekaligus menjadi pondasi yang sangat signifikan dikembangkan di wilayah tujuan.

Berbeda dengan itu, visi dari kaum Alawiyyin adalah menyebarkan pesan religiusitas dan moralitas untuk mencapai derajat ketakwaan pada Allah SWT. Melanjutkan tugas kenabian menjadi tujuan utama kehadiran kaum Alawiyyin di setiap wilayah syiar dan dakwahnya, dan menjadikan modus kehidupan Nabi sebagai panduan atau cetak biru dalam menjaga kualitas keseimbangan antara urusan duniawi dan ukhrawi. Konsepsi ini sangat lekat dengan konsepsi humanisme dalam agama Islam (Boisard, 1994).

Adanya perbedaan motivasi ini cukup jelas menggambarkan pemosisian kaum Alawiyyin mengambil peran melanjutkan tugas suci kerasulan yang diemban oleh leluhurnya yakni Rasulullah Muhammad SAW. Tugas ini tentunya membentuk pemahaman tersendiri terhadap dirinya, terhadap orang lain, dan terhadap lingkungan sosial yang lebih luas. Untuk itu, kerangka yang memungkinkan dalam memahami prinsip relasi kehidupan kaum Alawiyyin dalam dunia internal dan dunia eksternalnya adalah tidak menempatkan signifikansi kehidupan kaum Alawiyyin hanya bersumber pada ranah yang semata-mata bernilai manusia dan menolak (negation) hakekat ruh dan penyingkiran ma'nawiyah secara gradual dalam kehidupan manusia.

Kerangka pikirnya sejatinya memahami bahwa pada dasarnya manusia itu terbenam dalam al Muhith Yang Ilahi ini. Hanya saja ia tidak menyadarinya, lantaran kelupaan dan kelalaiannya. Inilah awal mula terjadinya kekotoran jiwa, yang pembersihannya harus kembali mengingat Tuhan (dzikir). Mengingat Tuhan berarti melihat-Nya di mana-mana dan mengalami realitas-Nya sebagai al Muhith itu. Mengingat Tuhan sebagai al Muhith berarti menyadari terus-menerus kualitas sakral alam, realitas fenomena alam sebagai "ayat-ayat Tuhan, dan kehadiran lingkungan alam sebagai suatu bagian yang dimungkinkan oleh kehadiran Yang Ilahi (Maksum, 2003). Artinya kajian ini telah mengungkapkan bahwa kehidupan sosial kaum Alawiyyin sebagai realitas yang secara ontologis tidak terpisahkan dengan lingkungan Ilahi.

Perwujudannya adalah kaum Alawiyyin lebih awal membentuk arena sosialnya dengan merelasikan nilai-niai keluhuran yang diinternalisasi dari gurunya di Hadramauwt. Melalui modus kehidupan nabi yakni Sunnah dan Al-Qur'an dapat membentuk keyakinan dan ketakwaan kepada Allah SWT, dan juga berkontribusi positif dalam menjaga dan memelihara garis keturunan (genelogi) kaum Alawiyyin di tengah arena kehidupan sosial. Aparatus yang mendukung stabilitas, konsistensi dan loyalitas penduduk lokal menjadi muhibbin dan perpaduan dengan penduduk lokal adalah melalui, siara kubur, pembacaan ratib, zikir, da'wah, muhibbin, tasawuf, tawassul, pernikahan se-kafaah, majelis, pesantren, masjid, sedekah. 


\section{Penutup}

Kaum Alawiyyin, sebagai salah satu suku bangsa yang terlahir dari proses migrasi dari negeri Hadramauwt membangun keunikannya melalui keluhuran nilai leluhurnya, genealogi yang bersambung dengan Rasulullah dan praktek relasi dalam kehidupan sosial. Kaum Alawiyyin alih-alih membangun kesamaan untuk menciptakan kepaduan dengan penduduk lokal, mereka justeru mengaktifkan kanon yang berbasis pada kesejarahan Rasulullah SAW sebagai leluhurnya. Metode ini juga berkontribusi meneguhkan turunan kaum Alawiyyin dan posisisnya sebagai komunitas diaspora di kepulauan Maluku. Sebagai turunan Nabi dan Rasul Muhammad SAW, kaum Alawiyyin dapat dikatakan senantiasa mengkonstruksi relasinya dengan kehidupan sosial dalam kerangka ketahuhidan Islam. Kendatipun hidup dalam era modern yang lebih menekankan pada rasionalitas, kaum Alawiyyin justeru mengaktifkan model relasi yang tidak melakukan pemisahan (negation) keberadaan keyakinan religius dengan kehidupan sehari-hari. Idealnya, menjadi keniscayaan manusia dalam hubungannya ke atas sebagai "hamba Allah", sedangkan ke bawah sebagai khalifah Allah SWT. Keduanya bukanlah sesuatu yang terpisah tetapi senantiasa bersinergi dalam berbagai ekspresi membentuk penghambaan (al ubudiyyah) terhadap Allah SWT. Struktur relasi kaum Alawiyyin kemudian dapat tetap terjaga dan operasional di beberapa komunitas karena kaum Alawiyyin bersama dengan sejumlah ulama lebih awal membangun/membentuk arenanya melalui syiar dan dakwah agama Islam. Model relasi seperti ini juga membentuk satu kesadaran berislam bagi masyarakat di kepulauan Maluku yang sangat potensial dalam menjaga garis keturunan sebagai kaum Alawiyyin yang bersambung ke Rasulullah Muhammad SAW.

Sementara dari sudut pandang penduduk lokal, melalui wujud relasi yang dipraktekkan oleh kaum Alawiyyin di kepulauan Maluku, mereka menganggap kaum Alawiyyin sebagai parner/teman yang membawa dunia lokal menjadi sesuatu yang kosmopolitan, yang menghubungkan dengan dunia lain dalam dimensi Islam. Orang lokal menjadi mengglobal, karena ia membangun moral geografi yang bersifat mendunia dan menjadi lebih beradab.

\section{Ucapan Terimakasih}

Proses penelitian dalam kajian ini format dasarnya berlangsung pada saat riset disertasi saya di Departemen Antropologi FISIP UI yang berjudul Praktik Penciptaan Jalinan Sosial (Sociality) Tariqah Alawiyah Bagi Kaum Alawiyyin Di Kepulauan Maluku. Untuk itu, pada kesempatan ini saya menyampaikan terimakasih kepada Prof. Dr. Yasmien Zaky Shahab (Promotor), Prof. Eng Seng Ho (Ko-Promotor) dan Dr. Tony Rudyansyah, MA (Ko-Promotor) yang telah mengajarkan banyak hal dalam kajian etnografi, memberikan banyak masukan pada saat penelitian dan penyusunan disertasi. Termasuk memotivasi menulis dalam bentuk artikel. Terimakasih juga kepada Muhammad Alagil selaku ketua Arabia Asia Studies, Asia Research Institute, Nasional University of Singapura (NUS) yang telah memberikan dukungan berupa dana penelitian. Namun demikian terkait dengan isi dan analisis yang ada dalam artikel ini adalah sepenuhnya menjadi tanggung jawab penulis. 


\section{Conflicts of interest}

Penulis menyatakan tidak ada konflik kepentingan.

Referensi

Aidid, M. H. (1999). Petunjuk Monogram Silsilah Berikut Biografi dan Arti Gelar Masing Masing Leluhur Alawiyyin. Amal Saleh.

Alatas, I. F. (2012). Ismail Fajrie AlatasThe Ba Alawi in the Interstices of the Nation. Antropologi Indonesia, 33(2).

Arab, L. S. I. dan B. A. (1994). Kerangka Memahami Islam. Al Izzah.

Assegaf, A. A. (1994). Lintasan Awal Sejarah Islam di Indonesia. Perpustakaan Jamiat Kheir.

Boisard, M. A. (1994). Humanisme dalam Islam. Bulan Bintang.

Hatta, A., \& Dkk. (2013). The Great Story of Muhammad SAW. Referensi Lengkap Hidup Rasulullah SAW dari Sebelum Kelahiran Hingga Detik-Detik Terakhir. Maghfira Pustaka.

Ho, E. (2006). The Graves of Tarim: Genealogy and Mobility Across the Indian Ocean. The Univ of California. University of California Press.

Hurgronje, C. S. (n.d.). Kumpulan Karangan Snouck Hurgronje Jilid 1, 2 dan 3. INIS.

Hurgronje, C. S. (2019). Orang Aceh. IRCiSoD.

Kesheh, N. M. (2007). Hadrami Awakening. Akbar.

Kiymlicka, W. (2011). Kewargaan Multikultural. LP3ES.

Koenjtaraningrat. (1993). Masalah Kesukubangsaan dan Integrasi Nasional. UI Press.

Magenda, B. D. (2005). Dinamika Politik Keturunan Arab di Tingkat Lokal. Antropologi Indonesia, 29(2).

Maksum, A. (2003). Tasawwuf Sebagai Pembebasan Manusia Modern Telaah Signifikansi Konsep "Tradisionalisme Islam" Sayyed Hosein Nasr. Pustaka Pelajar dan PSAPM.

Muhaimin, A., \& Wahab, A. (2014). Sayyid Idrus Bin Salim Al Jufri Pendiri Alkhairat dan Kontribusinya dalam Pembinaan Umat. Gaung Persada Press.

Muhammad Hasan Al-Aydrus. (1996). Penyebaran Islam di Asia Tenggara. Lentera.

Nina, J. (2012). Perempuan Nuaulu, Tradisionalisme dan Kultur Patriarki. Yayasan Pustaka Obor.

Patji., A. R. (1988). Asimilasi Golongan Etnis Arab dalam Stereotip Etnik, Asimilasi, Integrasi Sosial. PT. Pustaka Grafika Kita.

Reysyahri, M. (2015). Citra Ahlulbait Nabi SAW. Penjelasan Ayat dan Riwayat. Penerbit Nur Al-Huda.

Rudyansjah, T. (2009). Kekuasaan Sejarah dan Tindakan. Sebuah Kajian Tentang Lanskap Budaya. Rajawali Pers.

Sila, A. (2004). Gender and Etnicity in Sayyid Community of Cikoang, South Sulawesi. Kafa' ah Marriage System Among Sayyid Females. Antropologi Indonesia, 29(1).

Slama, M. (2014). Indonesian Hadhramis and the Hadhramaut: An Old Diaspora and its New Connections. Antropologi Indonesia. https:/ / doi.org/10.7454/ai.v29i2.3531

Trijono, L. (2001). Keluar dari Kemelut Maluku. Refleksi Pengalaman Praktis Bekerja untuk Perdamaian Maluku. Pustaka Pelajar. 